\title{
PHYSICIANS, SCIENCE, AND STATUS: ISSUES IN THE PROFESSIONALIZATION OF ANGLO-AMERICAN MEDICINE IN THE NINETEENTH CENTURY
}

\section{S. E. D. SHORTT*}

THE professionalization of Anglo-American medicine, most scholars would agree, took place during the nineteenth century. But how this process occurred or, indeed, what the term itself signifies, encourages no such consensus. This confusion may be a reflection of the relatively little historical curiosity sparked by those individuals or institutions subsumed under the diffuse designation "middle class". The professions, a significant feature of middle-class culture, have inspired "house histories of professional bodies", 1 but such studies are in general "so thin and lacking in critical framework as to be of almost no use to succeeding scholars". ${ }^{2}$ Faced with the analytical vacuum in existing literature, the historian may turn to studies by sociological colleagues. To the uninitiated, the works encountered present both a taxonomic quagmire and a series of theoretical constructs quite at odds with the historian's principal concerns. Since most of the sociologist's formulations are derived from current practice, they are likely to produce what one historian has called "nonsensical results" when applied to the historical process. Lyell, Herschel, and Darwin, for example, would find themselves excluded from the ranks of professionals by a twentieth-century definition of scientist emphasizing specialized training and income derived from the sale of that expertise. ${ }^{3}$ Neither does such terminology take into account vestigial criteria. To the earnest Victorians, for example, the attainment of professional status was intimately linked to the possession of "character", a nineteenth-century cipher signifying a range of "enduring credentials" such as "mental initiative, self-reliance, and usefulness".4 Confronted by such difficulties, it

*S. E. D. Shortt, MD, PhD, Hannah Professor of the History of Medicine, Queen's University, Kingston, Ontario, Canada K7L 3N6.

An earlier version of this paper was presented to the Workshop on Professionals and Professionalization in the Nineteenth and Twentieth Centuries at the University of Western Ontario, London, Canada, March 1981 .

\footnotetext{
'Harold Perkin, 'Social history in Britain', J. soc. Hist., 1976, 10: 140-141.

${ }^{2}$ Charles Rosenberg. 'The medical profession, medical practice and the history of medicine', in Edwin Clarke (editor), Modern methods in the history of medicine, London, Athlone Press, 1971, p. 27.

${ }^{3}$ Susan F. Cannon, Science in culture: the early Victorian period, New York, Dawson and Science History Publications, 1978, pp. 142-143.

4 Bernard Bledstein, The culture of professionalism: the middle class and the development of higher education in America, New York, W. W. Norton, 1976, ch. 4.
} 


\section{S. E. D. Shortt}

seems reasonable to accept Nathan Reingold's warning that historians "simply cannot use the definitions of professionalism that appear in most of the current sociological literature."s As will be clear from works referred to below, sociology is a useful source of insight and methodological innovation; its conceptualizations and definitions, however, must not be borrowed indiscriminately.

The historian's definition of professionalization, then, is at present best left deliberately vague. But as Thomas Haskell has recently argued, "Our inability to agree on an exact line of demarcation between amateur and professional, or profession and nonprofession, does not make these categories themselves unintelligible."'6 For the purposes of this paper, medical professionalization may be said simply to denote a process by which a heterogeneous collection of individuals is gradually recognized, by both themselves and other members of society, as constituting a relatively homogeneous and distinct occupational group. ${ }^{7}$ One component in this transformation, most scholars would concede, is the tendency for the emerging group to coalesce around a particular configuration of knowledge. It is this process, in reference to nineteenth-century medicine, which provides the focus for the present discussion. It must be stressed, however, that the evolving relationship between the medical profession and its reservoir of knowledge was not by any means the only significant factor in the professionalization process; economic aspirations, demographic shifts, and alterations in disease patterns, among other considerations, must share the responsibility. Rather, the present concern is, first, to suggest that the traditional assumption linking the professionalization of medicine in a causal fashion to a growth in scientific knowledge requires substantial modification. Such modification, it will next be argued, is unlikely to derive from that school of recent historiography which stresses the unscientific character of nineteenth-century Anglo-American medicine. Finally, a more fruitful approach will be identified in the work of scholars who appreciate both the cultural or nontechnical value of science and the social diversities within the medical profession itself. From such a review, some insight may be gained into the general relationship between professionals and the knowledge to which they lay claim.

A cursory survey of any standard work on medical history reveals the accumulation of a number of significant biological and medical innovations during the nineteenth

\footnotetext{
s Nathan Reingold, 'Definitions and speculations: the professionalization of science in America in the nineteenth century', in A. Oleson and S. C. Brown (editors), The pursuit of knowledge in the early American republic: American scientists and learned societies from colonial times to the civil war, Baltimore, Md., and London, Johns Hopkins University Press, 1976, p. 37. This is not to suggest that sociology makes no contribution to a historical appreciation of professionalization. Frequently praised works by sociologists include: Eliot Friedson, Profession of medicine: a study of the sociology of applied knowledge, New York, Harper \& Row, 1970; Geoffrey Millerson, The qualifying associations: a study in professionalization, London, Routledge \& Kegan Paul, 1964. A number of historians borrow profitably from sociology as will be seen from the works by Peterson, Thackray, and Inkster noted below.

- Thomas Haskell, ‘Are professors professional?', J. soc. Hist., 1981, 14: 490.

'A useful descriptive framework for studying this transition is George Daniels, 'The process of professionalization in American science: the emergent period, 1820-1860', Isis, 1967, 58: 151-166. Such an approach, however, does not account for the process it describes.
} 
century. The period opened shortly after Jenner's description of smallpox vaccination and drew to a close with the introduction of diptheria antitoxin by Behring and Kitasato. Numerous bacteriological discoveries were made in the interim. In the fiveyear period from 1879 to 1884 , the causative organism was identified for leprosy, typhoid, malaria, tuberculosis, diphtheria, cholera, and tetanus. Though these diseases awaited a cure, physicians had refined their pharmacopoeia to exclude the worst excesses of heroic therapy and concentrated, instead, on a handful of efficacious remedies such as digitalis, morphine, and aspirin, only some of which had been available early in the century. Even more impressive was the now-credible alternative of surgery. With the introduction of ether anaesthesia in 1846 and antisepsis after Lister's work in 1867, a successful outcome seemed less dubious and was doubtless reinforced when, in 1895, radiology enhanced diagnostic acumen. Underlying these developments was a major change in the conception of the disease process itself. Beginning with Bichat's work in histology early in the century, the remnants of humoralism were attacked and finally abandoned after Virchow applied Schwann's cellular concept to pathology. Theory and practice seemed to have benefited from a steadily escalating series of biomedical innovations. ${ }^{8}$

If medical knowledge was transformed over the course of the nineteenth century, most historians agree that the character of the profession was significantly altered as well. In the United States, a scant four medical colleges existed in 1800, but another seventy-three institutions were established by 1877.9 Though the quality of medical education varied enormously, and though licensing requirements were chaotic until after $1870,{ }^{10}$ the professional gradually accumulated a variety of unifying institutions. Between 1797 and 1850, 117 American medical journals appeared; at the end of the century, 275 periodicals were published in the United States. By 1830, nearly all states in the Union possessed a medical society and these were supplemented by many local societies. On a national level, the American Medical Association, organized in 1847, was joined by another fifteen national speciality groups between 1864 and 1902.11 Each of these trends, although with significant national idiosyncrasies, was evident elsewhere in the nineteenth-century Anglo-American medical world. In Upper Canąa, for example, six medical acts betwen 1795 and 1865 attempted to regulate physicians, many of whom graduated from the five domestic schools established between 1824 and 1854. These individuals gathered to form local, provincial, and national medical associations by 1880 , and published a number of medical journals,

\footnotetext{
- These events are described in standard histories of medicine and are listed by year in Fielding $\mathrm{H}$. Garrison, An introduction to the history of medicine, 4th ed., Philadelphia, Pa., and London, W. B. Saunders, 1929, pp. 839-845.

' Martin Kaufman, 'American medical education', in Ronald L. Numbers (editor), The education of American physicians, Berkeley, Los Angeles, and London, University of California Press, 1980, p. 11.

${ }^{10}$ Martin Kaufman, American medical education, the formative years, 1765-1910, Westport, Conn., and London, Greenwood Press, 1976, ch. 5; Richard Shryock, Medical licensing in America, 1650-1965, Baltimore, Md., Johns Hopkins University Press, 1967, ch. 1. Note also Joseph Kett, The formation of the American medical profession: the role of institutions, 1700-1860, New Haven, Conn., Yale University Press, 1968.

${ }^{11}$ James G. Burrow, A.M.A., voice of American medicine, Baltimore, Md., Johns Hopkins Press, 1963, pp. 10-11; Shryock, op. cit., note 10 above, p. 23; John Duffy, The healers: a history of American medicine, Urbana, Chicago, and London, University of Chicago Press, 1979, 301.
} 


\section{S. E. D. Shortt}

seven of which appeared during the 1870 s alone. ${ }^{12}$ Such acts of professional delineation mirrored those of the mother country. The private medical schools which had proliferated in London following the Apothecaries Act of 1815 were supplemented by medical schools associated with University and King's Colleges by 1840 and by a significant number of provincial schools beginning with Manchester in 1824.13 The graduates of these schools provided members for groups such as the Provincial Medical and Surgical Association, founded in 1832 and re-named the British Medical Association twenty-four years later, the National Association of General Practitioners, and a host of local or specialized organizations. By 1858, the profession, in contrast to the American experience, secured in the General Medical Council a national method of differentiating between qualified and unqualified practitioners. ${ }^{14}$ By the 1880 s, then, a physician in the Anglo-American medical world could point to educational facilities, licensing standards, medical societies, and periodicals - the hallmarks, it is said, of professionalization - most of which had been unavailable to practitioners in the early decades of the century.

Biomedical innovation and professional delineation were clearly events which, during the nineteenth century, occurred in parallel. Traditional historiography, however, has assumed a more intimate relationship, arguing that the new science increased competence and competence brought professional recognition and status. This thesis, in fact, is so fundamental to the structure of many older works, that it remains an implicit assumption scarcely requiring overt formulation. ${ }^{15}$ In part, the popularity of this perspective is a reflection of views forcibly expressed by participants in nineteenth-century medical research. Rudolf Virchow, for example, commented in 1877 that "even the external character of medical practice has changed in the last thirty years" since "Scientific methods have been introduced everywhere into practice". ${ }^{16}$ Forgotten are the views of the Cambridge physiologist, Michael Foster, or

${ }^{12}$ Elizabeth McNab, A legal history of the health professionals in Ontario: $A$ study for the committee on the healing arts, Toronto, Queen's printer, 1970, pp. 5-20; G. W. Spragge, 'The Trinity Medical College', Ontario History, 1966, 58: 63-98; C. G. Roland, 'Ontario medical periodicals as mirrors of change', ibid., 1980, 72: 3-15.

${ }^{13}$ F. F. Cartwright, $A$ social history of medicine, London and New York, Longman, 1977, pp. 53-54; F. N. L. Poynter, 'Medical education in England since 1600', in C. D. O'Malley (editor), The history of medical education, Berkeley, Los Angeles, and London, University of California Press, 1970, pp. 240-242. See also F. N. L. Poynter (editor), The evolution of medical education in Britain, London, Pitman Medical, 1966.

${ }^{14}$ Noel Parry and Jose Parry, The rise of the medical profession: a study in collective social mobility, London, Croom Helm, 1976, pp. 128-129; M. Jeanne Peterson, The medical profession in mid-Victorian London, Berkeley and London, University of California Press, 1978, pp. 19-20; Cartwright, op. cit., note 13 above, pp. 56-57.

is See, for example, Garrison, op. cit., note 8 above, especially pp. 407, 750-751; and Charles Singer and E. Ashworth Underwood, A short history of medicine, 2nd ed., Oxford, Clarendon Press, 1962, especially pp. 742-747. This perspective continues to dominate popular accounts, e.g. Steven Lehrer, Explorers of the body, New York, Doubleday, 1979. Recent critique of this tradition includes S. E. D. Shortt, 'The new social history of medicine: some implications for research', Archivaria, 1980, 10: 5-22; Susan Reverby and David Rosner, 'Beyond the "Great Doctors", in their edited Health care in America; essays in social history, Philadelphia, Pa., Temple University Press, 1979, pp. 3-16; John Woodward and David Richards, 'Towards a social history of medicine', in their edited Health care and popular medicine in nineteenthcentury England: essays in the social history of medicine, London, Croom Helm, 1977, pp. 15-55.

${ }^{16}$ Rudolf Virchow, 'Standpoints in scientific medicine' (1877), trans. by L. J. Rather, Bull. Hist. Med., 1956, 30: 543 . 
his French counterpart, Claude Bernard, which suggested that practitioners had received little benefit from medical science. ${ }^{17}$ Instead, Virchow's position has been reinforced by the subject matter which has traditionally attracted the attention of medical historians. Biography has been a common format which, by focusing on dramatic discoveries by celebrated physicians, has necessarily stressed the contributions of science to the profession. Among the various medical subspecialities, public health and surgery appear to have attracted particular interest. Practitioners in these disciplines, more so than in areas such as general practice or internal medicine, were likely to benefit in a tangible fashion from biomedical research. A third area of scholarly interest comprises what Charles Rosenberg has referred to as the "centennial" genre: ${ }^{18}$ laudatory histories of medical schools and hospitals designed to celebrate the scientific accomplishments of a particular local community. In the majority of cases, the authors of such studies were themselves physicians and were committed to the belief that science both represented the progressive alleviation of human suffering and provided an increasingly accurate basis for medical practice. Particularly in works appearing in the nineteenth century, the propagation of this message to members of the profession was an important motive for scholarly activity. ${ }^{19}$ The legacy of this heuristic intent was a historiography which linked science and professionalization in a causal relationship.

That such assumptions continue to inform historical scholarship, albeit in more sophisticated guise, is evident from an examination of William Rothstein's influential study of American physicians in the nineteenth century. Professionalization, he argues, resulted from "responses to two major causal forces - the body of medical knowledge used by physicians at any given time and the economic interests of physicians in earning a livelihood"' ${ }^{20}$ As the century opened, physicians had recourse to only three forms of what Rothstein refers to as "valid" therapy; that is, only some surgical procedures, anti-malarial cinchona bark, and smallpox vaccination, had "a high degree of therapeutic value with practically no side effects". ${ }^{21}$ Particularly under the stress of events such as the cholera epidemics of the 1830s, the therapeutic impotence of the regular practitioners became obvious and occasioned the rise of Thomsonian herbalists, homoeopaths, and eclectic practitioners. Faced with the economic challenge of sectarian medicine, physicians responded by forming orthodox medical societies and by assuming a more critical attitude to time-honoured but ineffectual therapies such as bloodletting, purging, and blistering. After mid-century, they adopted an increasing body of valid therapeutics, particularly surgical anaesthesia and antisepsis, which, in turn, strengthened their claims to professional

\footnotetext{
${ }^{17}$ Cited in Gerald Geison, 'Divided we stand: physiologists and clinicians in the American context', in Morris Vogel and Charles Rosenberg (editors), The therapeutic revolution: essays on the social history of American medicine, Philadelphia, University of Pennsylvania Press, 1979, p. 70. Geison quotes Virchow's essay from a different source and draws a similar contrast.

18 Rosenberg, op. cit., note 2 above, p. 27.

19 See Whitfield J. Bell jr., 'Practitioners of history: Philadelphia medical historians before 1925', Bull. Hist. Med., 1976, 50: 72-92; and Genevieve Miller, 'In praise of amateurs: medical history in America before Garrison', ibid., 1973, 47: 586-615.

${ }^{20}$ William G. Rothstein, American physicians in the nineteenth century: from sects to science, Baltimore, Md., and London, Johns Hopkins University Press, 1972, p. 4.

${ }^{21}$ Ibid., pp. 9, 10, 27.
} 


\section{S. E. D. Shortt}

legitimacy. One ironic but significant measure of their success in delineating a widelyaccepted orthodoxy by the end of the century was the precipitous increase in malpractice litigation. Only when measured against an absolute standard of scientific validity could a practitioner be found deficient. For Rothstein, then, economic competition and scientific innovation became locked in a symbiotic relationship as the underlying dynamic of professionalization.

While there is doubtless some substance to the traditional analytical framework, particularly when incorporating an awareness of the link between economic vicissitudes and changing medical theory, on closer examination it fails to confront significant methodological problems. Not only does its uncritical use of the term science tend to obscure important contours in the variegated fabric of nineteenthcentury thought, but, as a corollary, the nature of the medical profession itself is misconstrued by failing to appreciate the diversity of its components. A theory of professionalization based on such misconceptions becomes a dubious formulation. Unfortunately, as will be argued in the next section of this paper, much recent historiography, while introducing modifications of detail, serves largely to perpetuate these distortions. A critique of the newer works will apply with equal justification to the traditional approach described above.

\section{II}

A number of medical historians have, in the last decade, set themselves the revisionist task of demonstrating and explaining the isolation of nineteenth-century Anglo-American physicians from European biomedical research. That this approach fails to transcend the existing paradigm is apparent from the type of evidence assembled and the manner in which it is analysed. In the period from 1840 to 1870 , the argument runs, the twenty-two English contributions to physiology, a discipline seldom taught in either the London hospital schools or the universities, were dwarfed by some four hundred German accomplishments. The standard British work on the subject by William B. Carpenter "continued to combine moral with physiological instruction" in an effort "to preserve the notion of free will". This metaphysical preoccupation was linked to the popularity of William Paley's natural theology which stressed the evidence of God's design as the unifying principle of scientific study. Such a perspective supported the anachronistic British proclivity for anatomical investigation in preference to an experimental methodology. 22 When experimentation was attempted, it met a chorus of protest from the antivivisection movement, a lobby which enjoyed little popularity on the Continent. ${ }^{23}$ The relatively sluggish development of physiology was both an example of the low regard in which life sciences were

${ }^{22}$ Gerald Geison, 'Social and institutional factors in the stagnation of English physiology, 1840-1870', Bull. Hist. Med., 1972, 46: 31, 42, 35, 37, 39-41. See also his book, Michael Foster and the Cambridge school of physiology: the scientific enterprise in late Victorian society, Princeton, N.J., Princeton University Press, 1978.

${ }^{23}$ Richard D. French, 'Some problems in the foundations of modern physiology in Great Britain', Hist. Sci., 1971, 10: 28-55, and Antivivisection and medical science in Victorian society, Princeton, N.J., Princeton University Press, 1975. 


\section{Physicians, science, and status}

held when compared to geological or astronomical investigations ${ }^{24}$ and of the general lack of state encouragement for scientific research. ${ }^{25}$ British science drew on a lengthy tradition of individualism and "self-help", ${ }^{26}$ a heritage which prohibited the development of the decentralized, competitive academic centres deemed essential to a productive scientific community. ${ }^{27}$ Whatever medical science reached the British physician, then, was likely to bear a foreign imprint, an imprint that would both shape and significantly restrict the nature of the knowledge transmitted. ${ }^{23}$

Such imports were unlikely to originate in the United States. Though a diminutive scientific community had emerged there by the $1840 \mathrm{~s},{ }^{29}$ its interests were primarily with utilitarian investigations rather than theoretical pursuits. ${ }^{30}$ As in Britain, biological research was largely neglected in preference to geological exploration. ${ }^{31}$ During the first sixty years of the century, an estimated 3,200 Americans engaged in various forms of scientific research, ${ }^{32}$ yet the participation of physicians appears to have been of little significance. If, in the late eighteenth century, the American Academy of Arts and Sciences and the American Philosophical Society saw considerable medical activity, by 1800 this trend had dissipated. ${ }^{33}$ When the American Association for the Advancement of Science was established at mid-century, only eleven per cent of leadership positions were occupied by physicians. ${ }^{34}$ The sons of physicians were no more likely to enter scientific careers than those of farmers, clergymen, teachers, or tradesmen, and even in the life sciences less than one-quarter of the prominent scientists appear to have had medical training. ${ }^{35}$ Physiology did not appear as a distinct division of the medical curriculum until the 1880s and at least some physicians continued to lament the pernicious effect laboratory work would

${ }^{24}$ Cannon, op. cit., note 3 above, pp. 272, 274.

${ }^{25}$ Roy M. MacLeod, 'Resources of science in Victorian England: the endowment of science movement, 1868-1900', in Peter Mathias (editor), Science and society, 1600-1900, Cambridge University Press, 1972, pp. $111-166$.

${ }^{26} \mathrm{~J}$. B. Morrell, 'Individualism and the structure of British science in 1830', Hist. Stud. phys. Sci., 1971, 3: 183-204.

${ }^{27}$ Joseph Ben-David, 'Scientific productivity and academic organization in nineteenth-century medicine', Am. sociol. Rev., 1960, 25: 328-343.

${ }^{23}$ R. G. A. Dolby, 'The transmission of science', Hist. Sci., 1977, 15: 1-43.

29 Daniels, op. cit., note 7 above; Sally Kohlstedt, The formation of the American scientific community: the American Association for the Advancement of Science, 1848-60, Urbana, University of Illinois Press, 1976 , p.x.

${ }^{30}$ Daniels, op. cit., note 7 above, p. 161; Kohlstedt, op. cit., note 29 above, p. 2; Richard H. Shryock, 'American indifference to basic science during the nineteenth century', Arch. int. Hist. Sci., 1948-49, no. 28: 3-18, and reprinted in B. Barber and W. Hirsch (editors), The sociology of science, New York, Free Press of Glencoe, 1962, pp. 98-110; cf. Nathan Reingold, 'American indifference to basic research: a reappraisal', in George Daniels (editor), Nineteenth-century American science: a reappraisal, Evanston, IIl., Northwestern University Press, 1972, pp. 38-62.

${ }^{31}$ Kohlstedt, op. cit., note 29 above, pp. 61, 177; Robert V. Bruce, 'A statistical profile of American scientists, 1846-1876', in Daniels (editor), op. cit., note 30 above, pp. 69-70.

32 Reingold, op. cit., note 5 above, p. 62.

${ }^{33}$ James H. Cassedy, 'Medicine and the learned society in the United States, 1660-1850', in Oleson and Brown (editors), op. cit., note 5 above, p. 265. Steven Shapin and Arnold Thackray note a similar late eighteenth-century interest on the part of medical men in scientific pursuits in 'Prosopography as a research tool in history of science: the British scientific community 1700-1900', Hist. Sci., 1974, 12: 1-28.

${ }^{34}$ Kohlstedt, op. cit., note 29 above, p. 215.

${ }^{35}$ Bruce, op. cit., note 31 above, pp. $82,89$. 


\section{S. E. D. Shortt}

have on bedside competence. ${ }^{36}$ Few medical men were attracted to a poorly paid research career, techniques remained primitive, and government funds were almost non-existent. ${ }^{37}$ Like their British counterparts, those few nineteenth-century American physicians with an interest in medical science were forced to rely on reports of European research.

It might be objected, as, indeed, contemporary physicians did, that medical science was ignored because it was of little immediate value to the practitioner. But one historian has recently attempted to meet this objection by arguing that, even in their response to scientific innovations of direct clinical applicability, physicians apparently remained cautious and sceptical. Though Humphry Davy had suggested in 1800 that nitrous oxide might be used to relieve pain, anaesthesia was not introduced to surgical practice until the 1840 s. Despite its efficacy, it met a mixed reception. Some argued that pain was necessary to the course of natural tissue regeneration, while others saw it as an important restraint to inappropriately aggressive surgical procedures. Charles D. Meigs, a leading American obstetrician, spoke for those who believed pain to be an essential feature of normal obstetrical labour. The controversy which followed was more notable for its rhetoric than any concerted effort to gather clinical statistics. If it was resolved in favour of anaesthesia by the mid-1850s, it was barely in time to prepare for the emerging debate on antiseptic methods. Again, the work of early investigators such as Alexander Gordon (1795) or Oliver Wendell Holmes (1843) was ignored. In announcing his theory of wound management, Lister drew an implicit comparison between his own work and the less satisfactory practices of his colleagues. Damaged professional pride became one motive for ignoring his suggestions. Other surgeons, unable to grasp the range of procedures made possible by antisepsis, vigorously opposed a system which seemed to promise their own obsolescence. Even eminent practitioners such as Sir James Paget, though favourable to Lister's approach, clearly did not appreciate the microbiological theory upon which it was based. Not until at least fifteen years after the method was first described in the Lancet (1867), did a majority of the British profession accept its applicability. If prominent physicians in England were divided over the validity of what were the two most clearly efficacious discoveries of the century, A. J. Youngson feels justified in concluding: "Most doctors before 1850 , and many as late as $1870 \ldots$ simply did not observe or think scientifically", ${ }^{38}$

It would appear from such recent historiography, then, that science made little impact on medicine until the end of the nineteenth century. In fact, one could go further by adapting what Erwin H. Ackerknecht has referred to as "a behaviourist approach", and suggest that if the medical élite were resistant to innovation, isolated

${ }^{36}$ Geison, op. cit., note 17 above, pp. 72, 74.

${ }^{37}$ Edward C. Atwater, " "Squeezing mother nature": experimental physiology in the United States before 1870', Bull. Hist. Med., 1978, 52: 314, 326-327.

${ }^{38}$ A. J. Youngson, The scientific revolution in Victorian medicine, New York, Holmes \& Meier, 1979, pp. $45,87,106,107,114,116,130,131,174,182,191,199$. The quotation appears on p. 17. It is tempting to argue that the triumph of germ theory represented a revolution in the Kuhnian sense, while resistance to it suggested the last defence of an antiquated paradigm. See Thomas Kuhn, The structure of scientific revolutions, 2nd ed., Chicago, Ill., University of Chicago Press, 1970. 
general practitioners were doubtless even more so. ${ }^{39}$ By compressing the wider scientific achievements claimed for medicine by earlier historians into the final two decades of the century the revisionists would seem to have severed the link between science and medical professionalization. Unfortunately, the new approach, like the historiography it attempts to revise, is founded on a fundamental misconception of science. This misconception, whether termed Whig, positivist, or presentist, ${ }^{40}$ critically distorts the historical relationship between not just science and medicine, but science and society. Science is construed as a linear series of truths, each in turn awaiting inevitable recognition by a succession of astute investigators. In retrospect, a particular theory or innovation becomes "scientific" only when it is demonstrably a step on the path towards what is at present recognized as "true". Contrary opinions or viewpoints that eventually withered, regardless of their contemporary reception, are rejected as "pseudo-science" and their adherents scrutinized to explain either deceit or gullibility. Only recently have historians of medicine indicated that they are willing to transcend this paradigm and accept the fact that each age has a unique body of knowledge considered scientific. ${ }^{4}$ Such a revision, in turn, has significant implications for the linkage between medical knowledge and the process of professionalization.

An appropriate nineteenth-century example of the utility of a "pseudo-science" is the case of phrenology, a pursuit easily grouped with alchemy as a seemingly inauspicious vehicle for understanding medical science. It is irrelevant that this belief system subsequently made notable contributions to cerebral localization. ${ }^{42}$ The significant point is that, though eventually stigmatized as a fanciful theory of character and cranial bumps, in its heyday it was accepted, its craniology as much as its sophisticated revision of associationist psychology, by leading psychiatrists in England and the United States. It provided them with a credible theory for their assertion that insanity was a disease of the brain, and, therefore, potentially amenable to medical management, a viewpoint by no means universal in the $1830 \mathrm{~s}^{43}$ In effect, what is now labelled as an unscientific philosophy was assumed at the time to possess a high degree

\footnotetext{
${ }^{39}$ Erwin H. Ackerknecht, 'A plea for a "behaviourist" approach in writing the history of medicine', $J$. Hist. Med., 1967, 22: 211-214.

${ }^{4}$ Shapin and Thackray, op. cit., note 33 above, p. 2.

${ }^{11}$ An excellent example of the scrutinizing approach is Bernard Barber, 'Resistance by scientists to scientific discovery', in Barber and Hirsch (editors), op. cit., note 30 above, pp. 539-556. Some insight into the newer line of scholarship may be gained from: Robert M. Young, 'The historiographic and ideological context of the nineteenth-century debate on man's place in nature', in M. Teich and R. M. Young (editors), Changing perspectives in the history of science: essays in honour of Joseph Needham, Dordrecht and Boston, D. Reidel, 1973, pp. 344-438; Karl Figlio, 'The historiography of scientific medicine: an invitation to the human sciences', Comp. Stud. soc. Hist., 1977, 19: 262-286. Of relevance also is Keith Thomas's Religion and the decline of magic, New York, Charles Scribner's Sons, 1971, particularly ch. 7, in which he relates the efficacy of magical healing to the prevailing sixteenth-century cosmology.

${ }^{42}$ R. M. Young, Mind, brain and adaptation in the nineteenth-century, Oxford, Clarendon Press, 1970, and 'The functions of the brain: Gall to Ferrier (1808-1886)', Isis, 1968, 59: 251-268.

${ }^{43}$ R. J. Cooter, 'Phrenology and British alienists, c. 1825-1845, part I; converts to a doctrine', Med. Hist., 1976, 20: 1-21, and 'Part II: doctrines and practice', ibid., 1976, 20: 135-151. Margaret Pelling's recent Cholera, fever and English medicine, 1825-1865, Oxford University Press, 1978, makes a similar point by revealing the multiplicity of scientific theories advanced to explain cholera before 1850, most of which historians have previously ignored as irrelevant to the eventual emergence of germ theory.
} 


\section{S. E. D. Shortt}

of scientific validity and provided a crucial vehicle for legitimizing the aspirations of the "mad doctors".

Nor are such examples restricted to the realm of medical ideas: in therapeutics, "invalid" modalities lent similar credence to the stature of their purveyor, the physician. Nineteenth-century doctors and patients were united in what Charles Rosenberg has labelled "a conspiracy to believe", a willingness to accept medical science's definition of disease and its prescribed remedies. The body was conceived of as a dynamic balance of vital functions, while disease represented an intrusion which upset the delicate harmony. Treatment was intended to redress the disequilibrium largely through the physician's ability to "regulate the secretions". Within this theoretical context, "unscientific" procedures such as bleeding, purging, sweating, and blistering did work, for they exerted the expected effect on secretions and frequently showed other evidence of presumably efficacious physiological activity - alterations in pulse, changes in skin colour - as well. Therapy reassured to the degree that it demonstrably acted, and was given added credibility by the self-limited nature of most illnesses. The "physician's ability to understand and intervene in the ongoing physiological process which defined health and disease" was clearly revealed, while "the very severity of the drug action assured the patient and his family that something was indeed being done".44 And that something, it appeared, was a product of medical science.

The model of natural knowledge which emerged in the seventeenth century dualistic, atomistic, and mechanical - appeared to forge an immutable standard by which to measure the certainty of scientific thought. Construed in this sense, however, science assumes a historical constancy and is artificially aloof from the cultural context in which it is pursued. In implicitly adopting this perspective, much recent medical historiography fails to enhance an appreciation of the complex relationship between biomedical innovation and professionalization. More specifically, attempting to gauge with exactitude the extent to which nineteenth-century physicians were, by present standards, scientific, proves an unproductive task. Patients judged the profession by the criteria of their age, an authority which was incapable of distinguishing in any absolute sense the relative scientific merit of, for example, a phrenologist or his opponent. Given this limitation, "valid" science becomes irrelevant to the attainment of status, while to pursue diligently its antecedents adds little to an understanding of the past. What is of paramount importance, however, is the manner in which physicians used, not the content, but the rhetoric of science. In an analysis of the deployment of science by physicians it will become apparent that the nineteenthcentury profession, though outwardly demonstrating increasing homogeneity, must be resolved into a series of distinct and frequently competing subgroups. Each of these fragments invoked a definition of biomedical knowledge designed to accord with its particular aspirations. In effect, science, mirroring the profession itself, must be seen not as a fixed entity but as a collage of discrete and malleable constituents.

\footnotetext{
"Charles E. Rosenberg, 'The therapeutic revolution: medicine, meaning, and social change in nineteenth-century America', in Vogel and Rosenberg (editors), op. cit., note 17 above, pp. 7, 5, 6, 8, 9.
} 


\section{III}

In a significant revisionist commentary on the origins of modern British science, Arnold Thackray disputed the notion that the proliferation of nineteenth-century scientific endeavour could be explained largely as a response to the technological demands of industrialization. Rather, focusing on the evolution of the Manchester Literary and Philosophical Society, he argued that such activity must be seen primarily "as a mode of cultural self-expression" elaborated during "the social legitimation of marginal men". The eighteenth-century conception of natural knowledge as an appropriately genteel pursuit for aristocratic dilettantes was transformed, by 1840 , into an essential component in the value system of the entrepreneurial middle class. In the transformation period, Manchester played a significant role. It was a rapidly growing community of newly prosperous merchants and manufacturers, persons cut off from the rewards of landed English society by their occupations, Dissenting religions, and limited political force. Their espousal of science "can then be seen as deriving from their need to justify themselves, and to do so in terms of belief systems that simultaneously affirmed their commitment to high culture, announced their distance from the traditional value systems of English society, and offered a coherent explanatory scheme for the unprecedented, changeoriented society in which they found themselves". Science alone possessed the requisite characteristics to serve as a focus for this new identity. It was a form of polite knowledge signifying not only educational attainment, but also a respect for the theological implications of nature. If it provided rational, rather than frivolous, entertainment for some, to others it gave a calling, and to still others the technology with which to pursue their ambitions. Perhaps most significantly, "because the area of discourse was the natural rather than the moral world, and because all participants agreed that there existed impersonal and timeless laws of nature", it offered an ostensibly "value-transcendent" mode of communication. Science became, in effect, an "intellectual ratifier of a new world order" in which the descendants of the "closely knit, continually intermarrying, almost dynastic" marginal men of Manchester would play the central role. Marginality, through science, became centrality."s

4s Arnold Thackray, 'Natural knowledge in cultural context: the Manchester model', Am. hist. Rev., 1974, 79: 675, 678, 679, 682, 686, 693, 698. Cf. Everett Mendelsohn, 'The emergence of science as a profession in nineteenth-century Europe', in Karl Hill (editor), The management of scientists, Boston, Mass., Beacon Press, 1964, pp. 6, 32; and George Foote, 'Science and its function in early nineteenth-century England', Osiris, 1954, 11: 438-454. Both Mendelsohn and Foote emphasize the importance of technological utility as a motive for scientific investigation. Thackray's approach is adopted with profit by Morris Berman, Social change and scientific organization: the Royal Institution. 1799-1844, Ithaca, N.Y., Cornell University Press, 1978, particularly pp. xvii, 38, 71, 101-104, 123, 188, 189; and by Ian Inkster, 'Science and Society in the metropolis: a preliminary examination of the social and institutional context of the Askesian society of London, 1796-1807', Ann. Sci., 1977, 34: 1-32. The latter accords a larger role to utilitarian and financial incentives than does Thackray. More recently he has offered a telling critique of internal details of Thackray's analysis of the Manchester Literary and Philosophical Society and of his use of the term "marginal". He concedes, however, that the latter's socio-cultural view of science in the British industrial revolution remains viable. See Ian Inkster, 'Variations on a theme by Thackray: comments upon provincial science, culture, $c$. 1780-1850', British Society for the History of Science Newsletter, 1982, no. 8: 15-18. Significant, too, is Dolby, op. cit., note 28 above, p. 33, who warns that the same scientific concepts cannot be expected to perform identical social roles simultaneously in all communities. 


\section{S. E. D. Shortt}

Such an analysis suggests a fruitful approach to the manner in which physicians employed the rhetoric of science in their search for professional legitimation. ${ }^{46}$ In the past, English physicians of the period before the Medical Act of 1858 were described as apothecaries, surgeons, or physicians, a description which accords with the three legally recognized corporations of the period. ${ }^{47}$ In fact, this tripartite division evolved into the modern duality of general practitioner and consultant, despite legislation which appeared to preclude such a transformation. In 1834, for example, only 200 of the 6,000 members of the Royal College of Surgeons restricted themselves to the practice of surgery, but more than half the membership also held the licence of the Society of Apothecaries. Those accepting only surgical cases assumed consultant status in the emerging hospitals, while those with joint qualifications functioned as general practitioners in response "to the changing pattern of demand for health care... associated with the changes in the class structure brought about by the Industrial Revolution". What is lacking in this analysis is an explanation of how the new breed of local practitioner, in the absence of any demonstrable improvement in therapeutic efficacy, persuaded his middle-class patients of both his utility and social status. But that such a persuasion took place is clearly evident from the increased influence these individuals exerted within the medical community itself. Initially, the consultant élite, through their control of the Royal Colleges, dominated the profession, and the surgeon-apothecaries were "effectively divorced from the exercise of power within the profession". By the $1880 \mathrm{~s}$, the excluded had assumed sufficient importance to champion successfully a basic restructuring of not only British medical education and licensing, but the medical corporations themselves. The influence suggested by this victory derived from a number of factors but, to a significant degree, it was dependent on the earlier success in achieving professional recognition on a community level.48

The focus of analysis, then, for understanding the professional evolution of the British general practitioner must shift to the individual community, for it was here that legitimation first occurred. By forcing the rhetoric of science into the social vocabulary of the period, physicians secured a vehicle for their professional recognition. In early nineteenth-century Sheffield, for example, "the medical men were marginal twice over, for they were both provincials striving for individual status, and members of a profession yet in the making". Certification as late as 1858 could be held from any of nineteen English licensing bodies, such that "the layman could not immediately identify the status of any one medical man", nor could these individuals readily "gain the sanction of the community". The opening of the Sheffield Infirmary

\footnotetext{
46 In fact, a significant illustrative group in Thackray's analysis are medical men, op. cit., note 45 above, pp. 683-686. Cooter makes similar observations concerning the use of phrenology by English alienists aspiring to social legitimacy, op. cit., note 43 above, (Part I), pp. 11-12.

${ }^{47}$ See, for example, W. J. Bishop, 'The evolution of the general practitioner in England', Practitioner, 1952, 168: $171-179$.

4 Ivan Waddington, 'General practitioners and consultants in early nineteenth-century England: the sociology of an intraprofessional conflict', in Woodward and Richards (editors), op. cit., note 15 above, pp. 164-188. Quotations taken from 169 and 179. See also: S. W. F. Holloway, 'Medical education in England, 1830-1858: a sociological analysis', History, 1964, 49: 299-324; 'The Apothecaries' Act, 1815: a reinterpretation', Med. Hist., 1966, 10: 221-236; N. and J. Parry, op. cit., note 14 above, pp. 104-161.
} 
(1794) and the establishment of groups such as the Society for Literary Conversation (1806) provided, respectively, an institutional focus for practitioners and forums for the diffusion of medical knowledge. If, at the Society, addresses on, for example, the "Connections between Anatomy and Physiology" incorporated scientific discourse into the range of interest encompassed by polite learning, the opportunity to sponsor the Infirmary's charitable work provided an affirmation of benevolent respectability. The social contacts cemented in this process, buttressed often with shared religious and political perspectives, conferred on the marginal medical men a degree of "social comfort" by the 1840s.9 "Though therapeutic efficacy remained static, by ensuring that science became a component of middle-class discourse - a science for which they themselves were the local spokesmen - physicans had achieved social legitimacy. This legitimacy, in turn, was essential to the initial phase of professionalization.

A much different process with a similar finale may be discerned for another significant subgroup in the English medical community. The consultant élite, a numerically diminutive body, clustered in London and were distinguished by their membership in the Royal Colleges and close ties to the hospitals and medical schools. As an élite within their own sphere, they gained admission to the upper echelons of non-medical society by conforming to the values prevalent in that milieu. Lacking marginality, it was unnecessary to deploy science; rather, to gain their essential hospital appointments from the lay boards of governors they espoused the liberal learning and gentlemanly deportment valued by such groups. Clinical acumen, research publications, and teaching ability were extraneous to the criteria which determined status. It was only after mid-century, in order to gain autonomy from lay control within the hospital system, that the rhetoric of science became of value. ${ }^{50} \mathrm{~A}$ rising - indeed, pervasive - Victorian middle-class concern for matters of health ${ }^{\mathbf{s 1}}$ provided the necessary intellectual environment for the success of this appeal. Normal physiology and the pathological conditions of the body were, it now appeared, areas of expert knowledge no longer accessible to the layman. In this situation, the physicians "gained stature not because they could always act effectively, but because only they could name, describe and explain".s2 It was science which, by providing the vocabulary for this exegesis, secured professional independence for the London medical élite. That therapeutics remained circumscribed and theoretical assumptions little different from previous decades was largely irrelevant to this transformation.

The terminology of science, then, had entered the substratum of nineteenth-century British thought at a level quite divorced from its practical achievements. This subtle invasion made a significant contribution to medical professionalization: physicians portrayed themselves as exemplars of science to a public receptive to the idiom in which these claims were phrased. Under the guise of an objective explanation of

\footnotetext{
49 Ian Inkster, 'Marginal men: aspects of the social role of the medical community in Sheffield, 1790-1850', in Woodward and Richards (editors), op. cit., note 15 above, pp. 128, 131, 140-143, 149.

so Peterson, op. cit., note 14 above, pp. 123-124, 141-145, 281, 285.

51 Bruce Haley, The healthy body and Victorian culture. Cambridge, Mass., and London, Harvard University Press, 1978, especially ch. 1.

32 Peterson, op. cit., note 14 above, p. 286. A similar process is evident in the rise of the English public health doctor. See Steven J. Novak, 'Professionalism and bureaucracy: English doctors and the Victorian public health administration', J. soc. Hist., 1973, 10: 440-462.
} 


\section{S. E. D. Shortt}

natural phenomena, science became a code-word for a methodology, a designation for specialized expertise, and a vehicle for social mobility. Though scientific concern in the United States appears to have found expression predominantly in the vocabulary of technology, the implications for social discourse may have been largely similar..$^{53}$ Unfortunately, existing historiography contains no detailed analysis of American physicians and their cultural aspirations comparable to the British studies by Peterson or Inkster. As Gerald Grob has observed, medical history in the United States is "neglected or subordinated" to other concerns, with little effort made to profit from the sophisticated "examples set by European scholarship". ${ }^{44}$ Despite these limitations, however, there is sufficient evidence in the literature to suggest, at least superficially, that American physicians were not unlike their British counterparts: specific subgroups within the profession fashioned their own definitions of science in their search for acceptable socioeconomic stature.

Science, it is clear, became the dominant focus of the American "self-culture" movement in the early decades of the century. From the Lowell Institute in Boston, where crowds of 2,000 gathered to hear Benjamin Silliman's chemistry lectures, to the countless lyceums directed by local clergymen or doctors, citizens encountered in scientific discourse expressions of bellicose nationalism, pragmatic rationales for thrift and industry, and certain evidence of a beneficient Deity. ${ }^{35}$ Such science was assimilated into the curriculum of the ante-bellum college and became an accepted facet of liberal education with little evidence of hostility on the part of theological authorities. ${ }^{36}$ The Darwinian controversy may have disrupted this harmony in the natural sciences, but it left the methodology of science clearly intact..$^{57}$ To ambitious young Americans late in the century, the virtues sought in a profession were the virtues of science: "a special understanding of the universe...that was neither artificial, arbitrary, faddish, convenient, nor at the mercy of popular whim".s8 It was such individuals who were to define the criteria for the "scientific management" of factories, schools, and government in the ensuing decades. 59 By the "progressive era",

\footnotetext{
${ }^{33}$ For a complex elaboration of the mediating role of science, see Karl Figlio, 'The metaphor of organization: an historiographical perspective on the bio-medical sciences of the early nineteenth century', $H$ ist. Sci., 1979, 14: 17-53. Failure to appreciate that technology as much as basic science hinged on the social implication of science and its methodology has led to a lengthy debate in American historiography. See note 30 above.

${ }^{54}$ Gerald Grob, 'The social history of medicine and disease in America: problems and possibilities', $J$. soc. Hist., 1977, 10: 342.

ss Margaret Rossiter, 'Benjamin Silliman and the Lowell Institute: the popularization of science in nineteenth-century America', New Engl. Quart., 1971, 44: 602-626; Kohlstedt, op. cit., note 29 above, pp. $1-18$.

${ }^{36}$ Stanley Guralnick, 'Sources of misconception on the role of science in the nineteenth-century American college', Isis, 1974, 65: 352-366.

${ }^{37}$ See the significant observations on this point in Cannon, op. cit., note 3 above, pp. 2-8, 260-277; and also Hamilton Cravens, The triumph of evolution. American scientists and the hereditary-environment controversy, 1900-1914, Philadelphia, University of Pennsylvania Press, 1978.

st Bledstein, op. cit., note 4 above, p. 90.

59 Daniel Nelson, Managers and workers: origins of the new factory system in the United States, 1880-1920, Madison, University of Wisconsin Press, 1975; Raymond Callahan, Education and the cult of efficiency: a study of the social forces that have shaped the administration of the public schools, Chicago and London, University of Chicago Press, 1962; Martin Scheisl, The politics of efficiency: municipal
} 
science was scarcely challenged as an ostensibly objective arbitrator of social relationships and political organization. ${ }^{60}$

In such an intellectual climate, appeals to science as the justification for professional prerogative were likely to find a receptive audience. During the second half of the century, degree-granting medical schools proliferated in response to a mounting clamour for their certification. ${ }^{61}$ That the degree was usually awarded after two short and repetitive years was of little significance compared to the imprimatur of scientific learning it conveyed. ${ }^{62}$ Yet if most physicians earned these credentials, American medical practice revealed a broad spectrum of styles and interests. Subgroups within it employed the rhetoric of science, often at the expense of colleagues, in their individual efforts to secure status and recognition. After the Civil War, for example, young neurologists attacked established alienists for their failure to rid nosology of antiquated terms such as "moral insanity" in light of developments in cerebral localization, cellular pathology, or hereditarian theory. ${ }^{63}$ That these new currents of thought made no significant contribution to institutional psychiatry was of less importance than the scientific terms in which they appeared to be couched. In a similar manner, armed with a vocabulary signifying scientific expertise, physicians in general hospitals displaced lay governors as the locus of decision-making. No longer would laymen presume to dictate criteria for admission, acceptable standards of physician and patient deportment, or even the modalities of therapy to be employed. In part, this transformation reflected the physician's increased ability to attract patients from the middle class, patients who had internalized the claims made for medical science, and whose money was now essential to the precarious finances of the charity hospitals. ${ }^{64}$ Yet the important shift in institutional power took place well before medicine could demonstrate the efficacy of its science.

Public health provided a particularly appropriate field in which a medical subgroup could advance its professional status in the name of science. In the 1870 s, the American public health movement was dominated by laymen and referred to its concern as "sanitary science", a designation which, while revealing the inroads already made by the vocabulary of medical science, accurately reflected the pre-

administration and reform in America, 1800-1920, Berkeley and London, University of California Press, 1977.

${ }^{60}$ Samuel Haber, Efficiency and uplift: scientific management in the progressive era, 1890-1920, Chicago and London, University of Chicago Press, 1964.

${ }^{61}$ See the interesting contrast with Canadian practice drawn by Joseph Kett, in 'American and Canadian medical institutions, 1800-1870', J. Hist. Med., 1967, 22: 343-356, and reprinted in S. E. D. Shortt (editor), Medicine in Canadian society: historical perspectives, Montreal, McGill-Queen's University Press, 1981, pp. 189-205.

62 Haskell, op. cit., note 6 above, p. 487.

${ }^{63}$ Nathan Hale, Freud and the Americans: the beginnings of psychoanalysis in the United States, 1876-1917, New York, Oxford University Press, 1971, chapter 3.

${ }^{64}$ Charles Rosenberg, 'Inward vision and outward grace: the shaping of the American hospital, 1880-1914', Bull. Hist. Med., 1979, 53: 346-391; idem, 'And heal the sick: the patient and the hospital in 19th-century America', J. soc. Hist., 1977, 10: 428-447; Morris J. Vogel, 'Patrons, practitioners and patients: the voluntary hospital in mid-Victorian Boston', in D. W. Howe (editor), Victorian America, Philadelphia, University of Pennsylvania Press, 1976, pp. 121-138; David Rosner, 'Medicine at the bedside: health care in Brooklyn, 1890-1915', in Reverby and Rosner (editors), op. cit., note 15 above, pp. 117-131. 


\section{S. E. D. Shortt}

ponderate emphasis on the morality of hygiene. ${ }^{65}$ Two decades later, the field belonged almost exclusively to those with medical training. These individuals, in contrast to most physicians, tended to come from patrician families, enjoyed a measure of financial independence, and frequently, after graduation from prestigious Eastern medical schools, had completed their training in Europe.66 For this group, bacteriology became "a vehicle for the infusion of science into medicine" which promised, as well, "to shore up their own claims to legitimacy". ${ }^{67}$ Like the consultant élite in England, they based their position more on the ability to offer aetiological explanation than on the ability, except in the cases of diphtheria and smallpox, to intervene in the disease process. Science to such physicians "referred to specific disciplinary advantages which training, affiliation and accreditation conferred". ${ }^{68}$ To the majority of private physicians, lacking these specific status aspirations, this perspective seemed irrelevant to both the financial demands of practice and the realities of the doctor-patient relationship. The reporting of tuberculosis patients, for example, was time-consuming, violated confidentiality, and, to those doctors who chose to believe the disease was largely hereditary, appeared to confer no social benefits. The obvious efficacy of diphtheria antitoxin could not be ignored, but to the private practitioner, public health inoculation programmes suggested growing competition for a diminished reservoir of patients. ${ }^{69}$ It was only in the twentieth century that most physicians came to accept the medical science proposed by the public health doctors as a valid basis for practice. Significantly, this acceptance hinged not on the proven validity of the public health position, but rather, on the economic exigencies of private practice.

The local practitioner, in fact, began to see science not as a threat but as a positive defence for his professional activity. This view was quite unrelated to the content of medical science. In the closing decades of the nineteenth century, many public health doctors had joined those affiliated with teaching hospitals and the large Eastern medical schools in urging the reform of medical education. A new programme based firmly on laboratory science, they believed, would improve both the efficacy and the image of physicians. ${ }^{70}$ Meanwhile, many general practitioners had become convinced that the profession was overcrowded, a situation which led not only to lower incomes but also to a variety of ethical abuses which stigmatized the entire profession. In the decade after 1900, these worried doctors swelled the membership of the American Medical Association from 8,400 to 70,000 . Like the public health and universityaffiliated doctors, they supported the demand of the AMA Council on Medical

\footnotetext{
${ }^{65}$ This statement applies equally to Canada. See S. P. Ketcher, 'Toronto's metaphysicians: the social gospel and medical professionalization in Victorian Toronto', HSTC Bulletin: Journal for the History of Canadian Science, Technology and Medicine, 1981, 5: 41-51.

6 Barbara Rosenkrantz, 'Cart before horse: theory, practice and professional image in American public health, 1870-1920', J. Hist. Med., 1974, 29: 57-59, 61; John Duffy, 'The American medical profession and public health: from support to ambivalence', Bull. Hist. Med., 1979, 53: 1, 7-8.

${ }^{67}$ Russell Maulitz, "Physician versus bacteriologist": the ideology of science in clinical medicine', in Vogel and Rosenberg (editors), op. cit., note 17 above, pp. 92, 104.

6 Rosenkrantz, op. cit., note 66 above, p. 63.

69 Ibid., pp. 65, 68-71; Duffy, op. cit., note 66 above, pp. 8, 10, 16.

${ }^{70}$ Robert Hudson, 'Abraham Flexner in perspective: American medical education, 1865-1910', Bull. Hist. Med., 1972, 56: 545-561.
} 
Education for the incorporation of scientific medicine into the medical curriculum in the belief that marginal schools would soon close and the volume of professional competition diminish accordingly. Indeed, from 1904 to 1910, almost twenty per cent of schools did close and, significantly, through the war years and beyond, the concern of rank-and-file members for medical science quickly abated. ${ }^{11}$ Like their counterparts in England, it is clear that various groups of American physicians fashioned their own distinct definitions of science in a manner calculated to enhance their professional status. ${ }^{22}$ It is in this sense that professionalization was inextricably linked to medical science.

What, then, may be said of the relationship between the status of nineteenthcentury physicians and growth in biomedical knowledge? It is clear that physicians persuaded a significant portion of the public to eschew unorthodox competitors in favour of their "scientific" medicine, a product often not demonstrably superior, yet frequently more expensive and less available. This act of intellectual closure, according to traditional historiography, occurred because orthodox physicians were the representatives of "true science"; as such, their gradual recognition as society's legitimate healers was both appropriate and inevitable. Revisionist historians have disputed this interpretation, arguing that an appreciation of "true science" was often lacking in even the most accomplished Anglo-American physicians. It must be assumed from their accounts that no significant links between professionalization and medical innovation were possible at least until physicians suddenly embraced valid science in the closing two decades of the century. Both of these perspectives, it has been argued, by employing an ahistorical definition of science and ignoring the diversities which characterized medical practitioners, fail to explore adequately the connexions between science and professionalization.

A more fruitful approach to this relationship appears to lie in a consideration of the nineteenth-century cultural context in which scientific innovation and the professional aspirations of medicine coincided. Just as the emergence of penology owed little to either an escalation in criminal behaviour or an understanding of deviancy and a great deal to alterations in a society's definition of crime ${ }^{73}$ so medicine gained prestige not through enhanced therapeutic efficacy, but as a result of an increasing public faith in the value of science. Certainly, on a personal level, some individual patients owed much to refinements in medical techniques and their perception of the profession doubtless reflected these experiences. Beyond such encounters, however, literate inhabitants of the nineteenth century appear to have internalized first the authenticity

\footnotetext{
$"$ Gerald Markowitz and David Rosner, 'Doctors in crisis: a study of the use of medical education reform to establish modern professional elitism in medicine', Am. Quart., 1973, 25: 83-107. Similar trends occurred in Canada. See: Daniel McCaughey, 'The overcrowding of the medical profession in Ontario: 1851-1911', paper presented to the annual meeting of the American Association for the History of Medicine, Toronto, May 1981; Colin Howell, 'Reform and the monopolistic impulse: the professionalization of medicine in the Maritimes', Acadiensis, 1981, 11: 3-22.

72 It is important to avoid false distinctions among intra-professional groups. Women physicians, for example, may have subscribed to the same interpretation of medical science as their male counterparts. See Regina Morantz and Sue Zschoche, 'Professionalism, feminism, and gender roles: a comparative study of nineteenth-century medical therapeutics', J. Am. Hist., 1980, 67: 568-588.

${ }^{73}$ Michael Ignatieff, $A$ just measure of pain: the penitentiary in the industrial revolution, 1750-1850, New York, Columbia University Press, 1978.
} 


\section{S. E. D. Shortt}

and then the utility of science as a mode of perceiving and responding to the external world. ${ }^{74}$ In this cultural climate, medicine's time had come. If protests were voiced against the activities of medical science ${ }^{75}$ and alternative forms of healing appeared in various guises, ${ }^{76}$ their very transience attested to the power of medicine's claim. Similarly, the purveyors of patent medicines were only too willing to invoke the imprimatur of science as testimony to the legitimacy of their products." That the public little understood the science in which they professed to believe ${ }^{78}$ simply lent support to medicine's assertion that physiology and pathology were subjects increasingly beyond the layman's comprehension. ${ }^{79}$ If medicine's science produced few cures, it did suggest satisfying aetiological explanations which, in their apparent objectivity, transcended time, place, and class. When, as in the case of medical attitudes towards birth control, these explanations confirmed traditional social values, their popular appeal was assured. ${ }^{80}$ It was within the context of this pervasive paradigm of natural knowledge that biomedical innovation contributed to the professionalization of medicine. By the end of the nineteenth century, Abraham Flexner notwithstanding, physicians had become the personification of omniscient science.

${ }^{74}$ See note 45 above and Shapin and Thackray, op. cit., note 33 above, especially p. 5.

${ }^{75}$ French (1975), op. cit., note 23 above; Lloyd Stevenson, 'Science down the drain, on the hostility of certain sanitarians to animal experimentation, bacteriology and immunology', Bull. Hist. Med., 1955, 29 : 1-26; Ann Beck, 'Issues in the anti-vaccination movement in England', Med. Hist., 1960, 4: 310-321; Martin Kaufman, 'The American anti-vaccinationists and their arguments', Bull. Hist. Med., 1967, 41: 463-478. Physicians themselves occasionally questioned the value of orthodox medical science. See John H. Warner, "The nature-trusting heresy": American physicians and the concept of the healing power of nature in the 1850's and 1860's', Perspecives in American History, 1977-78, 11: 291-324.

${ }^{76}$ Martin Kaufman, Homeopathy in America: the rise and fall of a medical heresy, Baltimore, Md., and London, Johns Hopkins University Press, 1971; Alex Berman, 'The Thomsonian movement and its relation to American pharmacy and medicine', Bull. Hist. Med., 1951, 25: 405-428, 519-538; Ronald Numbers, 'Do-it-yourself the sectarian way', in G.B. Risse et. al. (editors), Medicine without doctors: home health care in American history, New York, Science History Publications, 1977, pp. 49-72.

7 James H. Young, The toadstool millionaires: a social history of patent medicines in America before federal regulation, Princeton, N.J., Princeton University Press, 1961.

"See the revealing comment on this point by William $\mathrm{H}$. Walsh (1895) cited in Mendelsohn, op. cit., note 45 above, p. 3.

7 Peterson, op. cit., note 14 above, pp. 280-281, offers suggestive comments on this point.

* Angus McLaren, 'The early birth control movement: an example of medical self-help', in Woodward and Richards (editors), op. cit., note 15 above, p. 96; James Reed, 'Doctors, birth control, and social values: 1830-1970', in Vogel and Rosenberg (editors), op. cit., note 17 above, p. 111. 